\title{
School Entrepreneurship Extracurricular Management
}

\author{
Masruroh, Erny Roesminingsih, Totok Suyanto \\ Department of Educational Management \\ Universitas Negeri Surabaya \\ Surabaya, Indonesia \\ masruroh.17070845025@mhs.unesa.ac.id
}

\begin{abstract}
This research aims to: (1) Describe student planning process through the school entrepreneurship program; (2) Describe the process of fostering students through school entrepreneurship programs and (3) Explain the process of evaluating school entrepreneurship programs. This research is used descriptive qualitative approach with a case study method. Data collected using observations, interviews, and documentation method. Data analyzed using data collection, condensation, display and verification. The results showed that planning of school entrepreneurship extracurricular programs was based on an analyzes of the needs of students with involving stakeholders, then held an entrepreneurial selection network such as recruits, conducts, selection, acceptance, orientation and placement of students. The implementation of school entrepreneurship extracurricular programs is done with learning materials and practices that are realized through business day events and exhibitions. Supervision of school entrepreneurship extracurricular programs is done to evaluate student performance which consists of making business proposals, manufacturing products and marketing products.
\end{abstract}

Keywords-management; entrepreneurship; schools

\section{INTRODUCTION}

The developments of science and technology these days stimulate a change in education as well. Education is the key to determine the future in a country, because it holds the preparation for the better human resources. Therefore, to have human resources who have competence, skills, innovation power, and creativity in the era of the industrial revolution 4.0, it is necessary to have better planning. Developing human resources is not described and formulated clearly in regulation [1]. Education aimed to develop the abilities contained in learners so that it can create goals and function fully for himself and the community [2].

Schools should be a place where students can have the opportunity to experience learning with various activities in order to develop themselves in order to face competition in the industrial revolution 4.0. [2]. Student development through entrepreneurial activities can help students to face the real world of work in accordance with the talents and abilities of these students.

The phenomenon of the low interest students was taken place in non-academic field. The effort to maximize students' academic performance was made students' skills decrease so that they were being retarded and less confident. This is become serious problems faced by the school. Character building, achievement on non-academic skill and family environment, were made the teachers being challenged in nurture and guide the learner to produce better graduates.

Schools are expected to be the answer to these problems, thus we need to specialized programs that can support various skills of students through various activities in schools. Entrepreneurship is one field that can answer these needs. By studying entrepreneurship, students can learn to develop the skills, create new innovations and meet the needs of the wider community. Entrepreneurship can also be an answer to the challenges of students in facing the era of the industrial revolution 4.0 [3]. Thus, students are formed into strong in creative person.

The results of this study are in line with the results of previous studies. There is a previous relevant study held by Negin in 2018 titled "Barriers to entrepreneurship development in Iran's higher education". The author explains that the implementation of open and refined coding processes is illustrated in a four-dimensional model. This research model represents the upcoming context of entrepreneurship development in Iran's higher education system. Finally, causal conditions leading to such impact, consequences, and action strategies to reduce and alleviate the given impacts.

Development of creativity and innovation as a basis of entrepreneurship, accordance with Hao Ni (2018). The study results prove that the participation rate of entrepreneurship education in secondary vocational schools is much higher than in their counterpart (academic schools), with more than half of secondary vocational students reporting having received entrepreneurship education of diverse types. Motivation and leadership, as well as enterprise knowledge, play mediating roles through which entrepreneurship education affects entrepreneurial intention, and represent two types of entrepreneurial human capital that is entrepreneurial knowledge and entrepreneurial competence.

The same thought was stated at a research journal about entrepreneurship development pattern in college based on business incubator written by Bainil (2015). The author explain that the government has made an effort to promote entrepreneurship, but these efforts seem not show a significant impact due to the fact that many people who are not productive every year. This is applied to the management of higher education which benefits institutions and students by maximizing their potential. 
Entrepreneurship program builds students' academic and non-academic skills so that the students can be prepared to use the development of information technologies to increase the productivity and efficiency of students. Students also learn to capture business opportunities that arise as the information technology development in the industrial revolution 4.0. This is the challenge for education to changes the student learning pattern so that the student will be able to learn in various fields of science. [3]

Students Students need to be provided with entrepreneurial material so that when they graduate they become independent and have entrepreneurial characters. It does not mean that students get profit (money) from the sale only, but also the positive characters like honest, confident, responsible, innovative and courageous to take risks [4] in everyday life.

This research will be focused on student management through the school's entrepreneurship program in Junior High School which aims to implant the entrepreneurial spirit within the students.

\section{METHOD}

This research adopted qualitative approach, with a case study research, to conduct on objects that develop as they are, not manipulated by researchers [5]. The focus of this study is to describe school extracurricular program planning, process and evaluation.

This research's Informants as sources of research data were principals, deputy principals in the curriculum and student section, extracurricular teachers, students that consisted of: seventh grade and eighth grade.

Data collection is done by observation, interview, and documentation techniques [6]. Observation is carried out by direct observation of entrepreneurial activities. Documentation obtained from interview recording data, photos of student activities on entrepreneurship events, photos produced by students, photos of student activities that reflect entrepreneurial spirit. Meanwhile interviews were conducted to obtain data from informants. Furthermore, before the interview the researcher made interview guidelines, conducted research permits and made agreements for interviews with informants.

This study uses two models of analysis to sharpening the validity of the data namely triangulating methods and triangulating sources. After the validity of the data is done, the next steps in the data analysis phase are: data condensation, data presentation and conclusion or verification [7].

\section{RESULTS AND DISCUSSION}

This research results are focused on program planning, implementation and evaluation, that will be presented here. Program Planning and school policy in relation to the entrepreneurship program, was arranged by involving various persons such as: school board, the education officers, leader foundation, the school committee, the school principal, teachers, and school staffs. This is written in work plan schools after getting approval from those parties.

The person in charge of entrepreneurship development from junior high school is a school principal, assisted by vice principals that in charge of curriculum area to plan and arrange the program of entrepreneurship. The design of the curriculum involves all teachers for maximum results.

The entrepreneurship development done by teachers. Entrepreneurship takes part in lesson plan made by teacher. The teacher was the one who educate and guide students to do innovation development and evaluate entrepreneurship program.

Entrepreneurship process was start from recruiting students to join in the entrepreneurship. Recruitment conducted at the new school period (first week of August), only the students in seventh grade will attended this class because the eighth, and the ninth grade should focus on their subjects. In the flyer of recruitment there were some criteria that the students should meet to join in. In the end of recruitment process, the students should record their profile as the entrepreneurship members.

After the recruitment is done, the next step is to analyze the needs of students, through the direct interview. The students who pass the requirements and interview should make a statement of willingness to become a member. Students who have become members are given an entrepreneurial orientation. They will meet personally with friends and their coach, so they will be introduced to entrepreneurship materials and the essence of entrepreneurship.

The teacher should explain to students the steps that they must take part, the activities they should attend and the introduction of the products, for example: varied drinks like legen, degan, tea (sour soup leaf), snacks like sempol fish, main dish like rice burger, newspaper crafts, and decoupage.

The placement of students in the field of entrepreneurship was conducted in achievement grouping. By this grouping, the teacher could mix the students between the students who are well performed with students who are not well performed. [8].

There was a division between the girls and the boys in the school because of the school regulation. Within each group whether the boys or girls, there were two achievement grouping. The group of students with the high achievement that has a great motivation could help their friends on the other group that has the lower achievements. It could help all the students to motivate each other, so the learning process will produce not only the better result, but also the better environment.

The implementation of this entrepreneurship program creates the better view of education to facing the globalization issues. By taking this class, the students develop the values of entrepreneurial in their life. The stakeholders should be involved in the activities to support this entrepreneurship program. It in line with Mulyani. [9] that has said that 
entrepreneurship could be implemented integrally by various activities in schools. Entrepreneurship education system should be applied to the curriculum with various activities so the students could experience the entrepreneurship education since early stage.

Coaching and debriefing activities for students are carried out through extracurricular and school culture. Extracurricular is held every Saturday at 10.00 , this briefing is carried out in theory and practice, this is in line with the opinion of Mulyani [9] who states that to support the growth of national and regional human resources to include entrepreneurship education by developing a link and match model.

Practice learning and activity material are carried out in rotation between one group and another, and provide material according to the written schedule. The link and entrepreneurship match are applied in schools on the first Saturday of the first week and the two schedules are lectures, while the three and four groups are scheduled for practicing and vice versa, the entrepreneurship records the attendance of students. This activity introduces the entrepreneurial values of students in order to foster discipline, responsibility, and independence in producing student creativity products.

The Implementation of fostering students through entrepreneurial extracurricular activities. Entrepreneurship is one the extracurricular activities, aimed at instilling entrepreneurial spirit. In entrepreneurial extracurricular activities, students are guided from the basic stage to innovation and creativity to the practice of making products directly and learning to market the products. This activity guides students to start a business in order to have experience when living in the community [10]. Students are active in carrying out innovation and creativity in producing works and producing what the market needs now and in the future (market oriented).

The stage of coaching that implemented at school was gone well. It held on Saturday after school hours. Evidence of the performance of students in entrepreneurial extracurricular activities can produce products including: teh tie (sour soup leaf), sempol ikan, legend (legen degan), rice burger, paper craft, and decoupage. Producing practices and entrepreneurial sales transactions are realized in business day activities, and exhibitions

Business day is an entrepreneurial activity at School by involving all school members. Business day facilitates students to develop creativity, sell their own work, and produce students who have entrepreneurial character. In accordance with the opinion of Saroni [11] who states that Business Day can be used as the cultivation of entrepreneurial spirit to students. Cultivate the soul of confidence by building quality and creativity by selling works [12]. In addition, it can train students to learn from working together and be responsible. Students are trained to learn how to manage finances independently. To assess the business day process, the teacher coordinator makes a checklist list to evaluate the development and abilities of students, and make a record of profit from buying and selling. The note is a documentation that functions as the calculation of the amount of capital and the results obtained from the buying and selling process. So, that it can be identified by the advantages and disadvantages received by students.

Business day is conducted once a month. this activity emphasizes more on the practice of producing and selling snacks (catfish spikes), heavy food (burger rice), varied drinks (sour soup leaf tea and legen degan), and create something from already used materials such as; garbage and decoupage. Business day provides education for students to apply the spirit of social care and familiarize students to be helpful to those in need. For this reason, the profit of the sales was collected by the treasurers of the entrepreneurship groups, then they will donate it to the orphans in surrounding area.

Exhibition is an annual program aimed at honing and channeling, interests, talents, and abilities of students. With various fields, such as science, social, religion and entrepreneurship. This program provides various skills to students that can be tried by the students independently. Exhibition is an educational exhibition that contains the work of students both academically and non-academically. This activity is held in a day with various series of events, competitions and student creativity exhibitions. The competitions are including: khitobah (religious lectures), memorize qur'an and painting competition. Mainwhile the creativity of students is in the form of: entrepreneurial exhibition, display of archipelago dances, drama, Islamic bands, al banjari music and robotics. the creativity of students is in the form of: entrepreneurial exhibition, display of archipelago dances, drama, Islamic bands, al banjari music and robotics.

Preparation of exhibition activities takes 2 weeks before the exhibition day. The teacher guides and directs students to play an active role. Entrepreneurship exhibition (bazaar day) implementation concept and products are the same as business day, selling snacks selling value of five thousand rupiahs (5000) heavy food, variants of drinks, decoupage, tissue boxes from used aqua glasses, plastic snack bags, and pencil holder decorations from used newspapers.

Students are given assignments and form by the committee as an effort to exercise an attitude of responsibility for the tasks assigned. Students are divided into groups in several corners: science, social, religious and entrepreneurial corner. Each comers were showing the work and creations of students who have been made in school [13]. Exhibition trains students to apply entrepreneurial spirit honestly, be independent, innovate, lead and take risks. For the concept of this activity is an exhibition of the students, they play an active role in making and promoting their work.

This activity provides a reflection of knowledge and experience to students, that entrepreneurship requires perseverance and always innovates on goods that have been produced, the existence of social products can inspire students to pass on entrepreneurship [14]. After the industry visit is 
carried out, as proof of responsibility, students are given the task to make reports in accordance with their respective groups.

Fostering entrepreneurship through school culture. Entrepreneurship development at school, through school culture is realized in school activities. In accordance with the opinion of Mulyani, [9] who states that entrepreneurial values can be carried out into school culture. School culture is an activity and atmosphere of life in school, there is interaction between students and the academic community. The school culture at Bina Anak Sholeh Tuban reflects the value of positive student character in accordance with the school's vision of "Muslim personality and optimal achievement".

The form of school culture is the participation of school residents such as employees, teachers and students to support business day activities and exhibitions. They also provide motivation to students whose sales have not been sold, especially in the early classes. Through this activity, conditions will be created to support a competitive and pleasant entrepreneurial atmosphere for students. The forms of activities related to entrepreneurship education include the Dhuha Prayer in congregation to educate students to believe and devote to Allah, Dhuha prayer is beneficial for the success of life in the world and the hereafter.

School culture is also implemented in activities where literacy services provide various books to inspire the students about successful people. It can motivate students to learn about entrepreneurship so that they are inspired and aspire to become entrepreneurs. The purpose of entrepreneurship is to develop the ability of students to have entrepreneurial character such as having the power of creativity, independence, innovation, the courage to take the risk of being responsible and honest. This is in accordance with the opinion of Suherman who states that entrepreneurship education is a process of planting creativity and innovation in overcoming problems, obstacles to various risks and opportunities to succeed [15].

Evaluation activities for entrepreneurship program held to measure the success of entrepreneurship. The teachers assess the students as a member of this entrepreneurship program and determine which students are active throughout the program through summative and formative assessment. Formative assessment conducted two weeks after the event. In accordance with the opinion of Bainil Yuliana, who states that monitoring and evaluation related to business activities that implemented in timetables based on periodic reports can be made, based on weekly and monthly monitoring [16].

Summative assessment conducted in every semester. The assessment consists of writing tests, interview, performance assessment and the related matter of entrepreneurship. Performance evaluation held on the business day, exhibition day and visit by teachers and industry group summative conducted every one semester, the assessment may be writing tests and an interview, performance assessment and the related matter and entrepreneurship. Performance evaluation at an event business day, exhibition, visit done by teachers and industry group. Learning reports of entrepreneurship were made for this assessment need, so it can show the development of students and provide it to their parents. Evaluation of the entrepreneurship character can be measured with daily habit, such as independent, creative, confident and responsible [17].

\section{CONCLUSION}

Based on the results of research and discussion stated above, it can be concluded as following, first planning of students through entrepreneurship programs, conducted at the beginning of the new school year by the leadership of the foundation, school committees, principals and teachers. The program is approved in the meeting, written in the curriculum draft, then the teacher plans the recruitment of students, needs analysis, selection and orientation to students in entrepreneurial activities.

Second, the implementation of entrepreneurship development is carried out in various ways, including: integrated through extracurricular activities and school culture. Entrepreneurship development through extracurricular activities by means of performance practices is realized in business day events, exhibition and industry visit. This extracurricular activity was held on Saturday at 10 o'clock, but the marketing practice event was packaged in a business day, the implementation of the exhibition once a month with the concept of a school exhibition, while the exhibition and industry visited, once a year. Integration of school culture, its implementation through daily activities in schools, for example the Dhuha prayer program in congregation, this is an integration of entrepreneurial character values of students so that they are always responsible for carrying out their duties and worship.

Third, entrepreneurship education evaluation of students is done by writing tests, interviews and performance, performance tests are applied in business day, exhibition and industrial visits, by entrepreneurship teacher coordinators, then report on the results of activities to assess the development and abilities of students.

For the following suggestion, the researcher suggests to making storefronts for storing the work of students so that students work can be seen neatly. And Add a collection of books related to entrepreneurship so students are inspired to become entrepreneurs. So entrepreneurship values are integrated into all subjects and daily life both at school and at home.

\section{REFERENCES}

[1] O. Hamalik, Proses Belajar Mengajar. Jakarta: Bumi Aksara, 2010.

[2] H. Soetopo and W. Soemanto, Pengantar operasional administrasi pendiidikan. Jakarta: Bina Aksara, 2012.

[3] Z. W. Thomas and N. M. Scarborough, Entrepreneurship and new venture formation. New Jersey: Prentice Hall International, 2013.

[4] D. F. Peter, Inovation anda enterpreneurship. pratice, and principle, 2011. 
[5] R. K. Yin, Case study research : Design and methods (applied social research methods). Illinois: Sage Publications, 2009.

[6] J. W. Creswell, Qualitative inquiry and research design: choosing among five approaches. Illinois: Sage Publications, 2011.

[7] Milles and Huberman, Qualitative data analysis a sourcebook of new methods. California: Sage Publications, 2010.

[8] T. UPI, Manajemen pendidikan. Bandung: Alfabeta, 2013.

[9] E. Mulyani, "Model pendidikan kewirausahaan di pendidikan dasar dan menengah," Jurnal ekonomi dan pendidikan, pp. 58-59, 2010.

[10] K. Sibelius, A. Anja, and H. Länsman, "Sámi Re-imaginings of equality in/through extracurricular art education in finland," International Journal of Education and Arts, 2018.

[11] M. Saroni, Mendidik dan melatih entrepreneur muda. Yogyakarta: ArRuz Media, 2012.

[12] F. Hanging, "Gap analysis of current and desired states of entrepreneurship development component in the field of ICT in Iran," Technology and society, 2018.

[13] N. Ni and Y. Ye, "Entrepreneurship education matters: exploring secondary vocational school students entrepreneurial intention in china," Springer, pp. 409-418, 2018.

[14] R. Aidis, S. Estrin, and T. Mickiewicz, "Penelitian berjudul Instutional and entrepeneurship development in Rusia, a comparative persfective," Journal of Business Venturing, 2008.

[15] E. Suherman, Desain pembelajaran kewirausahaan. Bandung: Alfabeta, 2010.

[16] Y. Bainil, "Entreprenueship development pattern in college based business incubator," International Journal of Science and Research (IJSR), vol. 6, 2017.

[17] R. Aidis, S. Estrin, and T. Mickiewicz, "Size matters: entrepreneurial entry and govermant," Journal of Business Venturing, 2010. 